\title{
Quality Analysis of Islamic Education Problem Based on Higher Order Thinking Skill Class V SDS Budi Mulia Medan
}

\author{
Ali Imran Sinaga ${ }^{1}$, Salamuddin ${ }^{2}$, Alnida Azty ${ }^{3}$ \\ 1,2,3 Islamic Education, Universitas Islam Negeri Sumatera Utara, Indonesia \\ Email: rozinida85@gmail.com
}

\begin{abstract}
The purpose of this study was to analyze the theoretical quality of the subjects of Islamic Education class V SDS Budi Mulia is based on Higher Order Thinking Skill (HOTS) based on aspects of material, construction, language and based on HOTS based on Bloom's Taxonomy of cognitive domains. This research was conducted at SDS Budi Mulia Medan Tanjung Mulia Hilir District Medan North Sumatra Province and the subject and object of research are Islamic Education teacher class $V$ and Islamic Education questions in semester I Class $V$. The research method used is to use a qualitative approach and use the instrument of semester I Islamic Education questions and interviews with Islamic Education teachers to theoretically analyze the quality of items based on material, construction and language aspects and based on quality analysis of HOTS-based items. The results of the study of 35 multiple choice questions obtained the following results: (1) based on the analysis of the item quality aspects of the material feasibility of $91.42 \%$ (32 questions) worth using, there are some questions that do not meet the criteria such as material that is not in accordance with the composition, answer choices which is not homogeneous and logical and the existence of questions that do not have the answer key, (2) based on the analysis of the quality of the aspects of the construction feasibility of $88.57 \%$ (31 questions) are suitable to be used, there are some questions that do not meet the criteria such as the subject still gives clues to the answer key and the length of the choice of money answers are not the same, (3) based on the analysis of items about the aspect of language worthiness of $42.85 \%$ (20 questions) worth using, there are some questions that do not meet the criteria such as using language that is not in accordance with Indonesian language rules, and the choice of answers repeat the same word / group of words, and (4) Based on an analysis of the quality of items according to the Bloom domain's taxonomy cognitive can be concluded from 35 multiple choice questions obtained that there are 17 questions $(48.6 \%)$ including the LOTS questions category with details $C_{1}$ (remembering) $=8$ questions $(22.8 \%), C_{2}$ (understanding) $=3$ questions $(8,7 \%), C_{3}$ (applying) $=6$ questions $(17.1 \%)$. While the rest included in the HOTS questions category, however all of them were in the $C_{4}$ criteria (Analysis) $=18$ questions $\left(51.4 \%\right.$ ) while none of the questions were in $C_{5}$ and $C_{6}$. Keywords: problem analysis; Islamic education; HOTS
\end{abstract}

\section{Introduction}

Education is a very interesting world to be discussed and studied. Various problems are popping up more and more. It cannot be separated with the growing development of human thought in seeing the phenomena that occur and human awareness of the importance of education. Various changes that are always developing make humans are required to actively solve problems that occur (Lubis in Siregar, 2020). Harahap in Siregar (2020) states development is a process of developing a product and validating the effectiveness and efficiency of the product to be produced. 
Islamic Education Learning needs to get serious attention and its development is continuously evaluated, so that the learning objectives of Islamic Education taught can be achieved optimally and are able to develop the affective, cognitive and psychomotor aspects of students simultaneously. One of the appropriate evaluation media in Islamic Education learning activities is Class Based Assessment which has orientation to HOTS, where the assessment requires students to have expertise in creative, critical, innovative, argumentative thinking, solving problems, and expertise in making decisions, especially on material about Islamic Education.

Assessment is carried out to obtain quantity information (through tests by carrying out measurements) and quality data (questions, discussions, observations, and feedback) which are then used to consider and determine decisions about values. Through classroom-based assessments oriented to measuring high-level thinking ability of students, and based on Bloom's taxonomy, which includes three domains, affective, cognitive and psychomotor, it is hoped that the learning objectives of Islamic Education can be achieved, so as to be able to create students who are not only and -and remembering, restating, or returning without processing the Islamic Education learning, but they master these three domains and are able to apply Islamic Education material in daily life (Baharun and Sa'diyah, 2018:189).

\section{Review of Literatures}

According to Arikunto (2013:53) tests are tools or procedures used to find out or measure something in an atmosphere, by means and rules that have been determined, while Rasydin (2009: 11) defines tests as a number of questions that have right or wrong answers aimed at to measure one's ability level. If it is associated with an educational program in schools, then the test is an evaluation tool used to measure the ability of students. In addition, the test also serves as a measure of the success of learning programs in schools. The tests used at school are usually in the form of multiple choice tests and essay tests.

The final exam questions are in the form of multiple choice tests with five answer choices. According Sukardi (2011:125-126) multiple choice test items have all the requirements as a good test, which is seen from the objectivity, reliability, and distinguishing between successful and failing students. The advantages of this kind of test include being able to measure students' mastery of information, tests are more flexible, and answers can be corrected more easily and quickly; while the weaknesses include giving opportunities to students to guess answers.

Surapranata (2009:1) states that the question quality analysis is carried out to find out whether or not a problem is functioning, meaning that the item quality analysis is an activity of analyzing each item in detail using a particular testing method. Meanwhile, according to Suharsimi Arikunto (2013: 220) stated that the analysis of the quality of the test is an activity to examine the questions on each item or item in order to determine the quality of each item. Analysis of the quality of items is a systematic procedure, which will provide information that is very specific to the test items that we compile. Meanwhile, according to Daryanto (2008:179) revealed that the analysis of the quality of items is an activity carried out to identify good problems, bad and bad questions and obtain instructions to make improvements.

Sofyan (2019:3) states that HOTS for the first time was discovered by Brookhart or Susan M Brookhart as well as Associate Professor of Dusquance University. Brookhart in Sofyan (2019: 3) defines HOTS as a model as well as a method of transferring knowledge, 
critical thinking, and a means to solve problems. HOTS is a skill to combine, manipulate, and transform the knowledge and experience that is already owned to think critically and creatively in determining decisions and solving problems in new situations. (Rofiah, et al: 2013, 17-22).

HOTS is a measurement of the ability to think at a high level, that is thinking that is not just necessarily remembering, restating, or returning without processing. To improve the quality of an education it is necessary to improve the education, one of which is in terms of assessment, it is very important to develop HOTS-oriented assessment or higher-level thinking skills, namely: a thinking model that does not merely remember information, but invites students to think at the highest level in order to develop a learning environment where students become creators of new ideas, information analyzers and knowledge generators.

The concept of high order thinking skills is adapted from the cognitive level expressed in bloom's taxonomy. At least, there are three concepts of the bloom level that require students to think at a higher level. These three concepts are the basis of high order thinking skills, which refer to the activity of analyzing, evaluating, and creating knowledge that is adjusted according to conceptual, procedural and metacognitive (Arif, 2020). The mindset of students must be changed into a mindset that refers to HOTS-oriented thinking to trigger the development of more critical and more creative thinking power. HOTS in learning aims to improve the ability to think highly on students, so in this case the educator as a facilitator must facilitate students to become better thinkers and problem solvers by providing a problem that allows students to use higher-order thinking skills.

HOTS is the highest ability to think compared to just memorizing or retelling. In the view of Annuuru (2017) states that this ability was originally based on bloom's taxonomy which classifies various kinds of thinking skills from the lowest domain (knowledge, understanding, and application) to the highest (analysis, synthesis, and evaluation). It also added that high level thinking leads to training in the ability to think cognition for students by integrating facts and ideas during the process of analyzing, evaluating, to the stage of providing an assessment of ideas or facts found even in the hope of being able to create something from a work that has been observed.

According to Dini (2018:175) states that HOTS can be raised in a learning situation, students are able to change and create the knowledge they know to produce or create something new. Because in this case, students already know the differences in ideas concretely, procedures for arguing well, being able to solve problems, constructing construction properly, being able to hypothesize and understand in depth complex complex problems, and show their ability to reason. Widihastuti (2015:82) states that HOTS in the form of thinking ability which is in the highest classification, it means that it requires thinking more difficult than usual. HOTS includes implementing, analyzing, evaluating, and creating with a supporting system in the form of the ability to think critically, logically, systematically and analytically, the ability to make decisions quickly, and the ability to create renewable products in accordance with what he already knows.

\section{Research Methods}

The research method used is qualitative. Data collection techniques carried out by documentation and interviews. Data collection procedures are carried out with the stages of data collection, data reduction, data presentation, and drawing conclusions. Checking the validity of the data is carried out with four criteria, namely credibility, transferability, dependability, and confirmability. 


\section{Discussion}

Based on the research results of the analysis of the quality of items in the final assessment of the first semester of SDS Budi Mulia Medan or Islamic Education and General Character Education, including questions that are worthy of testing, but there are 2 questions that do not have answers, namely questions number 3 and number 28 due to statements that are not according to the question. Next there are still a number of questions that do not meet the characteristics of each aspect of the 35 questions.

Based on the analysis of the item about the aspect of the material feasibility of $91.42 \%$ (32 questions) worth using, there are some questions that do not meet the criteria as in; (1) the material asked in accordance with the composition (urgency, relevance of continuity, high daily use) is not fulfilled in question number 3, (2) the choice of homogeneous and logical answers is not fulfilled in questions number 2 and 28, and (3) there is only one answer key not fulfilled in questions 3 and 28 .

Based on the analysis of construction feasibility items about $88.57 \%$ (31 questions) are feasible to use, there are some questions that do not meet the criteria as in; (1) subject matter does not give a clue the answer key is not met in problem number 1, (2) the length of the choice of the same relative answer is not fulfilled in questions number 2, 4, 19 and 24, and (3) almost all of the questions do not meet the construction feasibility aspects of points 7,9 and 10 because almost all of these questions are not equipped with pictures, diagrams, tables and the like except questions no do not use the statement "all the answers above are true/false", as well as items the problem depends on the answer to the previous question.

Based on the analysis of the item about the aspect of Language feasibility by $42.85 \%$ (20 questions) worth using, there are some questions that do not meet the criteria as in; (1) use language that is in accordance with Indonesian language rules, not fulfilled in questions, 2, 3, $4,9,11,12,14,15,16,18,19,22,26$, and 28 , and (2) the answer choices do not repeat the same word / group of words, unless it is a unity of understanding. not fulfilled in questions, 1 , $4,6,14,14,23,24,30$, and 33 .

Based on the analysis of items according to the bloom taxonomy of 35 multiple choice questions it was found that there were 17 questions (48.6\%) included in the LOTS questions category. While $18(51.4 \%)$ questions were included in the HOTS questions category. The results of the analysis of material aspects of 35 questions, there are two questions, namely questions number 3 and 28, are not worth testing based on the material aspects because the questions are not in accordance with the competency, material and do not have answers.

The results of the analysis of the construction aspects show that all questions are worth testing, but there are some aspects that are not met, such as: (1) the main aspects of the questions do not give a clue the answer key found in the subject matter number 1 is the same as the answer key, (2) the long aspect of the relative answer choice there are the same in questions number 2, 4, 19 and 24 have a choice of answers whose length is not the same choice of key answers to one another, and (3) almost all questions do not meet the aspects of the feasibility of construction of points 7,9 and 10 because this problem does not equipped with pictures, diagrams except question number 7 , do not use the statement "all the answers above are true / correct", and the item depends on the answer to the previous question.

The results of the analysis of the feasibility aspects of the language there are several questions that do not meet the criteria as in; (1) using language in accordance with Indonesian 
rules, not fulfilled in questions, $2,3,4,9,11,12,14,15,16,18,19,22,26$, and 28 , and (2) answer choices do not repeat the same word / group of words, unless it is a unity of understanding. not fulfilled in questions, 1, 4, 6, 14, 14, 23, 24, 30, and 33.

The results of the analysis of questions based on Bloom's taxonomy concluded that from 35 multiple choice questions it was found that there were 17 questions $(48.6 \%)$ included in the LOTS question category, namely number problems; 1, 2, 4, 5, 6, 8, 14, 17, 20, 23, 24, $25,30,31,32,33$ and 35 . In the LOTS question category, the criteria for questions are distributed at each level with details a) $\mathrm{C} 1$ (remembering) $=8$ questions $(22.8 \%)$ questions number $1,4,23,24,25,30,33$ and $35, \mathrm{~b}) \mathrm{C} 2$ (understanding) $=3$ questions $(8.7 \%$ ) questions number 8,31 , and 32, c) C3 (applying) $=6$ questions (17.1\%) questions number 2, 5, 6, 14, 17 and 20 .

While $18(51.4 \%)$ questions were included in the HOTS questions category. This shows that half of the total questions are HOTS questions, which are numbers; 3, 7, 9, 10, 11, $12,13,15,16,18,19,21,22,26,27,28,29$ and 34, but all of them are in criteria C4 (Analysis) $=18$ questions $(51.4 \%)$ so there is no variation in HOTS-based compilation.

\section{Conclusion}

The conclusions of the study are as follows:

1. Analysis of the quality of items about the aspects of the feasibility of the material shows that $91.42 \%$ (32 questions) are suitable to be used, there are some questions that do not meet the criteria as in; (a) the material asked in accordance with the composition (urgency, relevance of continuity, high daily usage) is not fulfilled in question number 3 , (b) the choice of homogeneous and logical answers is not fulfilled in questions number 2 and 28, (c) there is only one key answer not fulfilled in questions 3 and 28 .

2. Analysis of the quality of the items concerning the feasibility of the construction shows that $88.57 \%$ (31 questions) is appropriate to use, there are some questions that do not meet the criteria as in; (a) the main problem does not give a clue the answer key is not fulfilled in question number 1, and (b) the length of the choice of answer is relatively the same as not fulfilled in questions number 2, 4, 19 and 24, c) almost all questions do not meet the construction feasibility aspects of point 7,9 and 10 because almost all of these questions are not equipped with pictures, diagrams, tables and the like except questions no do not use the statement "all of the answers above are true/false, and the items depend on the answers to the previous questions.

3. Analysis of aspects of the items language worthiness shows that $42.85 \%$ (20 questions) is suitable to be used, there are some questions that do not meet the criteria as in; (a) use language in accordance with Indonesian rules, not fulfilled in questions, 2, 3, 4, 9, 11, 12 , $14,15,16,18,19,22,26$, and 28, and (b) the choice of answers is not repeat the same word/group of words, unless it is a unity of understanding. not fulfilled in questions, 1, 4, $6,14,14,23,24,30$, and 33 .

4. Analysis of the quality of items according to Bloom's cognitive domain of cognitive domain can be concluded from 35 multiple choice questions obtained that there are 17 questions (48.6\%) including LOTS question categories namely number problems; 1, 2, 4, 5, 6, 8, 14, $17,20,23,24,25,30,31,32,33$ and 35 . In the LOTS question category, the question criteria are spread at each level with details: (a) C1 (remembering) $=8$ questions $(22.8 \%$ ) questions number $1,4,23,24,25,30,33$ and 35 , (b) C2 (understanding) $=3$ questions $(8.7 \%$ ) questions number 8,31 , and 32 , (c) C3 (applying) $=6$ questions $(17.1 \%)$ questions number 2, 5, 6, 14, 17 and 20. While 18 (51.4\%) questions belong to the HOTS question category. This shows that half of the total questions are HOTS questions, which are 
numbers; $3,7,9,10,11,12,13,15,16,18,19,21,22,26,27,28,29$ and 34 , but all of them are in criteria C4 (Analysis) $=18$ questions (51.4\%) this is because the form of the questions used is relatively the same for the 18 questions, namely presenting several statements and students analyzing the statements in order to determine the correct answer, whereas there are no questions in C5 and C6.

Suggestions can be given as follows: (1) the preparation of Islamic Education questions must be based on indicators of questions obtained from indicators of achievement of basic competencies and basic competencies of Islamic Education grade $\mathrm{V}$ that have been determined by the government not only based on textbooks or Student Worksheet books, (2) questions that are prepared must also have answers and meet the eligibility criteria based on material, construction and language, and (3) Islamic Education teachers are expected to be able to make questions based on quality analysis of items that develop students' higher order thinking skills or HOTS by arranging questions with diverse forms of HOTS questions so that it is not only on $\mathrm{C}_{4}$ but also on $\mathrm{C}_{5}$ and $\mathrm{C}_{6}$.

\section{References}

Arif, S. et al. (2020). Integration of High Order Thinking Skills in Research Method Subject in University. Britain International of Linguistics, Arts and Education (BIoLAE) Journal, 2(1); 378-383.

Annuuru, et al. (2017). Peningkatan Kemampuan Berfikir Tingkat Tinggi dalam Pelajaran Ilmu Pengetahuan Alam Peserta didik Sekolah Dasar melalui Model Pembelajaran Treffinger. Bandung: Departemen Kurikulum dan Teknologi Pendidikan FIP UPI.

Baharun H dan Sa'diyah K. (2018). Penilaian Berbasis HOTS Berdasarkan Taksonomi Bloom Pada Pembelajaran PAI. Riau: Hikmah, Jurnal Pendidikan Islam, Vol. 7 No. 2 JuliDesember 2018.

Daryanto. (2008). Evaluasi Pendidikan. Jakarta: Rineka Cipta.

Emi Rofiah, et al. (2013). Penyusunan Instrumen Tes Kemampuan Berpikir Tingkat Tinggi Fisika Pada Siswa SMP. Jurnal Pendidikan Fisika, 1.2 (2013).

Harun Rasydin dan Mansur. (2009). Penilaian Hasil Belajar. Bandung: Wacana Prima.

Rusydi Ananda. (2019). Perencanaan Pembelajaran. Medan: LPPPI.

Siregar, S. (2020). Extracurricular Implementation of Islamic Education in Character Building Students in MTs EX PGA UNIVA Medan. Budapest International Research and Critics in Linguistics and Education (BirLE) Journal. P. 965-973

Sofyan, F A. (2019). Implementasi HOTS pada Kurikulum 2013. Jurnal Inventa, 3 (1), ISSN: 2598-6244.

Suharsimi Arikunto. (2013). Dasar-Dasar Evaluasi Pendidikan Edisi 2. Jakarta: Bumi Aksara.

Sukardi. (2011). Evaluasi Pendidikan: Prinsip dan Operasionalnya. Jakarta: Bumi Aksara.

Sumarna Surapranata. (2009). Analisis, Validitas, Reliabilitas dan Interpretasi Ilmiah. Bandung: Remaja Rosdakarya.

Widihastuti. (2015). Model Penilaian untuk Pembelajaran Abad 21 (Sebuah Kajian untuk Mempersiapkan SDM Kritis dan Kreatif. Dalam Siti Hamidah, Sri Wening, dan Yuswati (Penyunting), Prosiding Seminar Nasional Pengembangan SDM Kreatif dan Inovatif untuk Mewujudkan Generasi Emas Indonesia Berdaya Saing Global (hlm.7786). Yogyakarta: Universitas Negeri Yogyakarta. 